\title{
ANEURYSMAL BONE CYSTS TREATED BY CURETTAGE, CRYOTHERAPY AND BONE GRAFTING
}

\author{
H. W. BART SCHREUDER, RENÉ P. H. VETH, MACIEJ PRUSZCZYNSKI, J. ALBERT M. LEMMENS, \\ HEIMEN SCHRAFFORDT KOOPS, WILLEMINA M. MOLENAAR
}

From the University Hospitals of Nijmegen and Groningen, The Netherlands

We treated 26 patients with 27 aneurysmal bone cysts by curettage and cryotherapy and evaluated local tumour control, complications and functional outcome. The mean follow-up time was 47 months (19 to154). There was local recurrence in one patient. Two patients developed deep wound infections and one had a postoperative fracture.

We compared our results with previous reports in which several different methods of treatment had been used and concluded that curettage with adjuvant cryotherapy had similar results to those of marginal resection, and that no major bony reconstruction was required.

We recommend the use of cryotherapy as an adjuvant to the surgical treatment of aneurysmal bone cysts. It provides local tumour control. Combination with bone grafting achieved consolidation of the lesion in all our patients.

J Bone Joint Surg [Br] 1997;79-B:20-5.

Received 16 July 1996; Accepted 9 September 1996

Aneurysmal bone cyst is a rare benign tumour-like lesion of bone of unknown origin. There is controversy as to whether it is a distinct radiological and pathological entity or a pathophysiological change superimposed on a preexisting lesion. ${ }^{1}$ Lack of understanding about its origin and growth makes treatment empirical. The most common treatment has been curettage with bone grafting which has

H. W. B. Schreuder, Orthopaedic Surgeon

R. P. H Veth, MD, PhD, Orthopaedic Surgeon, Professor of Orthopaedics

M. Pruszczynski, MD, PhD, Pathologist

J. A. M. Lemmens, MD, PhD, Radiologist

University Hospital St. Radboud, P O Box 9101, 6500 HB Nijmegen, The Netherlands.

H. Schraffordt Koops, MD, PhD, Professor of Surgery

W. M. Molenaar, MD, PhD, Professor of Pathology

University Hospital, Groningen, PO Box 30.001, 9700 RB Groningen, The

Netherlands.

Correspondence should be sent to Dr H. W. B. Schreuder.

(C)1997 British Editorial Society of Bone and Joint Surgery 0301-620X/97/17097\$2.00 a substantial rate of recurrence. ${ }^{2-6}$ Lower recurrence rates can be achieved by marginal or wide resection, but are accompanied by loss of bone and the need for reconstruction. $^{2,7,8}$ Intralesional resection or curettage with effective adjuvant therapy to extend the surgical margin has been advocated. 5 Since 1969 we have used cryotherapy as an adjuvant after intralesional resection and we now evaluate our results.

\section{PATIENTS AND METHODS}

We performed a retrospective study of all patients treated for aneurysmal bone cyst between 1969 and 1995. This included review of all patient records, radiographs and pathology reports. The diagnosis had been made on both radiological and histological examination. Only patients with the diagnosis of aneurysmal bone cyst and no other abnormal histological findings were included.

There were 12 females and 14 males (27 aneurysmal bone cysts). The mean age at which cryotherapy was first performed was 21.7 years (4.2 to 49.6) and the distribution is shown in Table I. The bones involved are shown in Table II.

All had been treated by curettage and cryotherapy. Age, gender, history, anatomical location, tissue pathology, complications, function after surgery and length of follow-up had been recorded. Staging was accomplished using the radiological criteria for benign lesions of bone defined by Enneking. 10

Operative treatment consisted of intralesional resection (curettage) after bony fenestration, followed by cryotherapy. Initially, this had been used by one ( 2 cases), two (4 cases) or three ( 2 cases) freeze-thaw cycles, pouring liquid nitrogen into the bony cavity. In the subsequent 19 cases, we used three cycles of freezing and spontaneous thawing with a machine which produced a liquid nitrogen spray. The progress of freezing was usually monitored by thermocouples. A temperature of less than $-50^{\circ} \mathrm{C}$ inside the cavity was considered to be lethal for remaining tumour cells. A thermocouple outside the cavity, preferably close to the neurovascular bundle, was used to prevent freezing of these structures. In many cases the cavity was filled with an autograft (4) or allograft (14) of bone. Spondylodesis was performed once. Preoperative antibiotic prophylaxis was used in all patients (Kefzol; Eli Lilly Nederland BV, Nieu- 
Table I. Details of studies on aneurysmal bone cysts

\begin{tabular}{|c|c|c|c|c|c|c|c|c|c|}
\hline \multirow[b]{2}{*}{ Authors } & \multirow[b]{2}{*}{ Number } & \multirow[b]{2}{*}{ Male } & \multirow[b]{2}{*}{ Female } & \multicolumn{6}{|l|}{ Age (yrs) } \\
\hline & & & & 0 to 10 & 11 to 20 & 21 to 30 & 31 to 40 & 41 to 50 & $>51$ \\
\hline${\text { Campanacci et } \mathrm{al}^{2}}^{2}$ & 198 & 83 & 115 & 63 & 94 & 20 & 12 & 8 & 1 \\
\hline Koskinen et $\mathrm{al}^{11}$ & 20 & 13 & 7 & 3 & 9 & 2 & 3 & 2 & 1 \\
\hline Martinez and Sissons $^{12}$ & 87 & 45 & 42 & 25 & 39 & 14 & 3 & 2 & 4 \\
\hline Morton $^{13}$ & 26 & 14 & 12 & 12 & 6 & 4 & 2 & 2 & - \\
\hline Nobler et $\mathrm{al}^{14}$ & 33 & 13 & 20 & 3 & - & 17 & 7 & 6 & - \\
\hline Ruiter et $\mathrm{al}^{6}$ & 105 & 46 & 59 & 39 & 50 & 13 & 2 & - & 1 \\
\hline Szendröi et $\mathrm{al}^{8}$ & 52 & 31 & 21 & 15 & 25 & 6 & 2 & 1 & 3 \\
\hline Vergel De Dios et al ${ }^{15}$ & 238 & 109 & 129 & 57 & 132 & 30 & 6 & 6 & 7 \\
\hline Schreuder et al & 26 & $14(54 \%)$ & $12(46 \%)$ & $5(19 \%)$ & $10(38 \%)$ & $5(19 \%)$ & $2(8 \%)$ & $4(15 \%)$ & - \\
\hline Total & 785 & $368(46.9 \%)$ & $417(53.1 \%)$ & $222(28.3 \%)$ & $365(46.5 \%)$ & $111(14.1 \%)$ & $39(5.0 \%)$ & $31(3.9 \%)$ & $17(2.2 \%)$ \\
\hline
\end{tabular}

Table II. Anatomical distribution of aneurysmal bone cysts

\begin{tabular}{|c|c|c|c|c|c|c|c|c|c|c|c|c|}
\hline Authors & Tibia & Femur & Vertebra & Pelvis & Humerus & Fibula & Foot & Hand & Ulna & Radius & Other & Total \\
\hline Biesecker et al $^{17}$ & 8 & 8 & 4 & 8 & 14 & 3 & 6 & 2 & 3 & 3 & 7 & 66 \\
\hline Campanacci et $\mathrm{al}^{2}$ & 48 & 35 & 20 & 28 & 15 & 14 & 8 & 8 & 6 & 3 & 13 & 198 \\
\hline Cole $^{7}$ & 5 & 2 & - & 6 & 4 & 2 & - & - & 2 & 2 & 2 & 25 \\
\hline Farcetti et al ${ }^{18}$ & 1 & 5 & 2 & - & - & 1 & 4 & - & - & 2 & 5 & 20 \\
\hline Koskinen et al ${ }^{11}$ & 3 & 3 & 1 & 2 & 6 & 2 & 1 & - & - & 1 & 1 & 20 \\
\hline Martinez and Sissons ${ }^{12}$ & 19 & 12 & 13 & 8 & 6 & 4 & 5 & 5 & 7 & 3 & 5 & 87 \\
\hline Morton $^{13}$ & 6 & 5 & 5 & 1 & 1 & 3 & 3 & - & 1 & - & 1 & 26 \\
\hline Nobler et $\mathrm{al}^{14}$ & 4 & 6 & 2 & 7 & 3 & 1 & 4 & - & 2 & 1 & 3 & 33 \\
\hline Ruiter et $\mathrm{al}^{6}$ & 15 & 13 & 14 & 8 & 7 & 11 & 7 & 10 & 2 & 3 & 15 & 105 \\
\hline Szendröi ${ }^{8}$ & 8 & 6 & 4 & 7 & 8 & 5 & 4 & 2 & 4 & 2 & 2 & 52 \\
\hline Vergel De Dios et al ${ }^{15}$ & 34 & 40 & 34 & 26 & 14 & 18 & 13 & 15 & 7 & 8 & 29 & 238 \\
\hline Schreuder et al & 6 & 8 & 2 & 3 & 4 & 2 & 2 & - & - & - & - & 27 \\
\hline Total & $\begin{array}{l}157 \\
(17.5 \%)\end{array}$ & $\begin{array}{l}143 \\
(15.9 \%)\end{array}$ & $\begin{array}{l}101 \\
(11.2 \%)\end{array}$ & $\begin{array}{l}104 \\
(11.6 \%)\end{array}$ & $\begin{array}{l}82 \\
(9.1 \%)\end{array}$ & $\begin{array}{l}66 \\
(7.3 \%)\end{array}$ & $\begin{array}{l}57 \\
(6.3 \%)\end{array}$ & $\begin{array}{l}42 \\
(4.7 \%)\end{array}$ & $\begin{array}{l}34 \\
(3.8 \%)\end{array}$ & $\begin{array}{l}28 \\
(3.1 \%)\end{array}$ & $\begin{array}{l}83 \\
(9.2 \%)\end{array}$ & 897 \\
\hline
\end{tabular}

wegein, The Netherlands).

Occlusive tourniquets were not used. Patients were not allowed to bear weight on the affected limb until there were signs of radiological consolidation.

The mean clinical follow-up was 47.4 months (19 to 154). Two patients had a follow-up of less than 24 months (19 and 22). Conventional plain radiography was used in the follow-up period. Functional assessment was performed at the most recent follow-up visit and consisted of operation-related complaints and physical examination.

\section{RESULTS}

We classified 11 aneurysmal bone cysts as aggressive and 16 as active. The presenting symptom was a pathological fracture in seven patients, pain or discomfort due to swelling in 17 and neurological symptoms in two (both of whom had vertebral lesions). There was only one local recurrence, a rate of $3.7 \%$. This cyst had been treated with one cycle of cryotherapy using the pouring technique.

Complications included two cases of deep wound infec- tion (7.4\%). Both were successfully treated by debridement and the implantation and subsequent removal of gentamicin-PMMA beads. After a fall due to breakage of a crutch handle one patient had a femoral fracture through the treated lesion; this was treated successfully by osteosynthesis. One patient with a sacral lesion had a temporary increase in neurological symptoms which resolved within three months. All bone grafts showed progressive consolidation and incorporation. At the most recent follow-up, 24 patients had normal function of the treated limb without discomfort. One had some loss of movement at the hip and one at the ankle. All patients resumed normal daily activities.

\section{DISCUSSION}

Aneurysmal bone cyst is common in adolescents and almost half of the patients are between 10 and 21 years of age. ${ }^{2,6,8,11-15}$ There is a slight predilection for females (Table I), and great variability in the clinical course. In most cases there is pain and swelling and sometimes a 
pathological fracture. When located in the vertebral column neurological symptoms, as well as pain, are likely to be present. Aneurysmal bone cysts can occur in any bone, but are more common in the metaphyses of the long bones, especially around the knee, and in the vertebral column (Table II). The demographic characteristics of our series do not differ significantly from the typical picture reported in the literature.

Aneurysmal bone cysts both erode and cause 'expansion' of underlying cancellous and cortical bone. ${ }^{2}$ Around the lesion there is always a shell formed by periosteal new bone and, although this may be only millimetres thick, it prevents direct extension into the soft tissues. ${ }^{16}$

The concept of aneurysmal bone cyst as a secondary phenomenon occurring in a pre-existing lesion is based on the fact that in approximately one-third of the cases a preexisting lesion can be identified, the most common of which is giant-cell tumour. ${ }^{1}$ Others are osteoblastoma, angioma and chondroblastoma. ${ }^{1,12,17}$ Less common associations include fibrous dysplasia, non-ossifying fibroma, chondromyxoid fibroma, solitary bone cyst, fibrous histiocytoma, eosinophilic granuloma, radiation osteitis and trauma. Malignant lesions, such as osteosarcoma (especially telangiectatic), fibrosarcoma and metastatic carcinoma may have similar radiological and histological features to aneurysmal bone cysts, ${ }^{6}$ so accurate diagnosis is essential before advising treatment.

We agree with the view that aneurysmal bone cyst is an entity on its own ${ }^{2}$ having unique clinical, radiological and diagnostic behaviour. The diagnosis should be made only after the exclusion of an underlying lesion which can produce similar features. Such other conditions should be labelled after their principal element with the added description 'cystic or haemorrhagic changes'. 2 Our study included only primary aneurysmal bone cysts with no other histological findings.

Because of this lack of understanding about the origin and growth of aneurysmal bone cysts a variety of treatments has been described. They include irradiation alone, or a primary surgical approach with or without some kind of adjuvant treatment. Theoretically, adjuvant therapy may consist of systemic chemotherapy, radiotherapy and physical adjuvants like phenol, hypertonic saline merthiolate, polymethylmethacrylate (PMMA) cement applied locally, and cryotherapy.

Chemotherapy and irradiation therapy have an effect on mitotically-active cells. Their influence on a benign lesion such as aneurysmal bone cyst is limited and we believe that they are inappropriate because of the side-effects. Although radiation therapy has been used, especially in sites of difficult surgical access, with good results (Table III), we do not advise it because of the risk of secondary sarcoma in the irradiated field.

Phenol is a non-selective cytotoxic agent and when applied directly to the surface of curetted tumours, it kills remaining residual tumour and normal cells. Used as an adjuvant after curettage of an aneurysmal bone cyst, the reported recurrence rate is $12.5 \%$ to $20 \% .^{22,23}$ Recurrence is probably due to its superficial action and the impossibility of penetrating the periphery beyond the surgical margin.

Table III. Different types of treatment and recurrence rates of aneurysmal bone cysts

\begin{tabular}{|c|c|c|c|c|c|c|c|c|c|c|c|c|c|c|}
\hline \multirow[b]{2}{*}{ Authors } & \multicolumn{2}{|c|}{ Irradiation } & \multicolumn{2}{|c|}{$\begin{array}{l}\text { Curettage + } \\
\text { irradiation }\end{array}$} & \multicolumn{2}{|c|}{$\begin{array}{l}\text { Curettage }+ \\
\text { bonegraft }\end{array}$} & \multicolumn{2}{|c|}{$\begin{array}{l}\text { Curettage + } \\
\text { cryobiopsy }\end{array}$} & \multicolumn{2}{|c|}{$\begin{array}{l}\text { Marginal } \\
\text { resection }\end{array}$} & \multicolumn{2}{|c|}{$\begin{array}{l}\text { Wide } \\
\text { resection }\end{array}$} & \multirow{2}{*}{$\begin{array}{l}\text { Mean } \\
\text { follow-up } \\
\text { (mth) }\end{array}$} & \multirow{2}{*}{$\begin{array}{l}\text { Time to first } \\
\text { recurrence } \\
\text { (mth) }\end{array}$} \\
\hline & $\mathbf{N}^{*}$ & $\mathbf{R} \dagger$ & $\mathbf{N}$ & $\mathbf{R}$ & $\mathbf{N}$ & $\mathbf{R}$ & $\mathbf{N}$ & $\mathbf{R}$ & $\mathbf{N}$ & $\mathbf{R}$ & $\mathbf{N}$ & $\mathbf{R}$ & & \\
\hline${\text { Campanacci et } \mathrm{al}^{2}}^{2}$ & 8 & 2 & 15 & 3 & 91 & 19 & - & - & 47 & 0 & - & - & 84 & 2 to 72 \\
\hline Cole $^{7}$ & - & - & 1 & 0 & 18 & 7 & - & - & 4 & 0 & 2 & 0 & $>24$ & $75 \%<24$ \\
\hline Clough and Price ${ }^{3}$ & 1 & 0 & 2 & 0 & 15 & 8 & - & - & 3 & 0 & - & - & 79 & 5 to 48 \\
\hline Farcetti et al ${ }^{18}$ & - & - & 3 & 0 & 11 & 2 & - & - & - & - & 6 & 0 & 116 & 3 to 4 \\
\hline Freiberg et $\mathrm{al}^{4}$ & - & - & - & - & 7 & 5 & - & - & - & - & - & - & $>24$ & $<14$ \\
\hline Koskinen et $\mathrm{al}^{11}$ & - & - & 1 & 0 & 14 & 2 & - & - & - & - & 5 & 0 & 54 & - \\
\hline Kreicbergs et $\mathrm{al}^{19}$ & - & - & - & - & 21 & 8 & - & - & - & - & - & - & $>24$ & - \\
\hline van Loon et $\mathrm{al}^{20}$ & 1 & 0 & - & - & 8 & 3 & - & - & - & - & 1 & 0 & 102 & 7 to 15 \\
\hline Marcove et $\mathrm{al}^{5}$ & 11 & 1 & - & - & 44 & 26 & 51 & 9 & - & - & - & - & 85 & 3 to 102 \\
\hline Nobler et al $^{14}$ & 6 & 1 & 1 & 0 & 18 & 6 & - & - & 4 & 2 & 4 & 0 & - & - \\
\hline Ruiter et $\mathrm{al}^{6}$ & 2 & 0 & - & - & 82 & 28 & - & - & 17 & 4 & 4 & 0 & $80 \%>24$ & - \\
\hline Slowick et $\mathrm{al}^{21}$ & 4 & 0 & - & - & 5 & 1 & - & - & - & - & 4 & 0 & 83 & 10 \\
\hline Szendröi et al $^{8}$ & - & - & - & - & 26 & 7 & - & - & 6 & 0 & 16 & 0 & $>24$ & 14 \\
\hline Vergel De Dios et $\mathrm{al}^{15}$ & 1 & 0 & 12 & 2 & 124 & 27 & - & - & - & - & 17 & 0 & $>24$ & $90 \%<24$ \\
\hline Schreuder et al & - & - & - & - & - & - & 27 & 1 & - & - & - & - & 47 & 36 \\
\hline $\begin{array}{l}\text { Total } \\
\text { Recurrence rates }(\%)\end{array}$ & 34 & $\begin{array}{c}4 \\
11.8\end{array}$ & 35 & $\begin{array}{c}5 \\
14.2\end{array}$ & 484 & $\begin{array}{l}149 \\
30.8\end{array}$ & 78 & $\begin{array}{l}10 \\
12.8\end{array}$ & 81 & $\begin{array}{l}6 \\
7.4\end{array}$ & 59 & $\begin{array}{l}0 \\
0\end{array}$ & & \\
\hline
\end{tabular}

* number of cases

$\dagger$ recurrences 

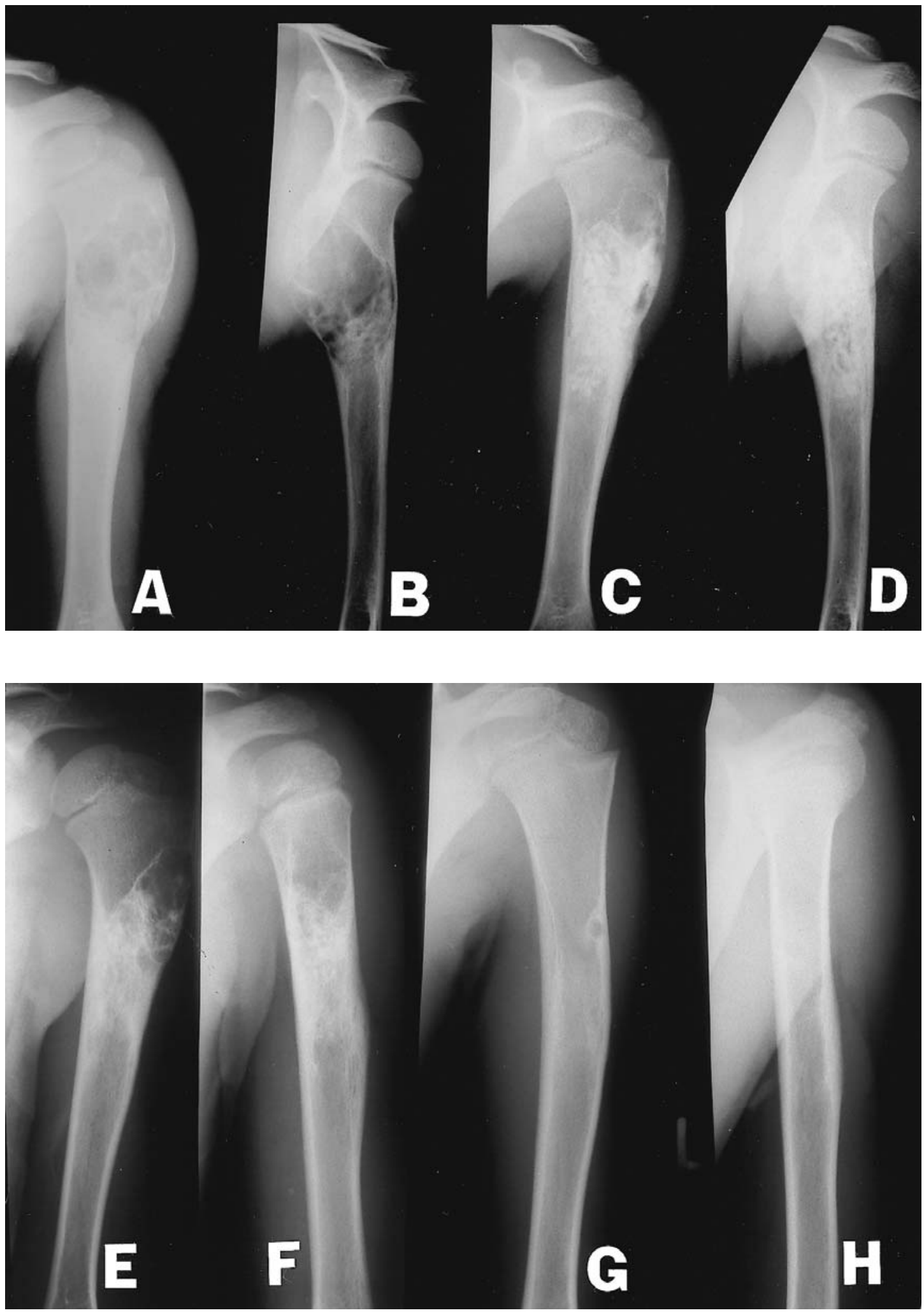

Fig. 1

Initial anteroposterior (A) and lateral (B) radiographs of an aneurysmal bone cyst in the proximal metaphysis of the left humerus of a four-year-old boy three months after curettage, cryotherapy and bone allograft $(\mathrm{C}$ and $\mathrm{D})$. One $(\mathrm{E}$ and $\mathrm{F})$ and four years $(\mathrm{G}$ and $\mathrm{H}$ ) later the bone has completely remodelled and the appearance of the intramedullary space is almost normal. 
The rationale of the use of PMMA cement as adjuvant treatment is based on its heating effect. Experiments have shown that a thermal lesion of at least $50^{\circ} \mathrm{C}$ is necessary for a cytotoxic effect. The maximum peripheral extent of a thermal lesion varies form $2.5 \mathrm{~mm}$ in cancellous to $0.5 \mathrm{~mm}$ in cortical bone. ${ }^{24}$ For local control of giant-cell tumours good results with recurrence rates of $5 \%$ to $15 \%$ have been reported, ${ }^{24,25}$ but no results are available for the use of PMMA cement as adjuvant treatment of aneurysmal bone cysts.

The most commonly used treatments and their recurrence rates are summarised in Table III. The recurrence rates for irradiation with or without curettage are similar, $11.8 \%$ and $13.8 \%$ respectively. Curettage with or without bone grafting is accompanied by a high recurrence rate of $30.8 \%$. Cryotherapy as an adjuvant after curettage has a recurrence rate of $12.8 \%$. Marginal and wide resection are associated with low rates, $7.4 \%$ and $0 \%$ respectively. In a review of 65 cases of aneurysmal bone cyst in the facial region, ${ }^{26}$ curettage was associated with a recurrence rate of $33 \%$, about the same as for non-facial lesions.

Cryotherapy using liquid nitrogen has been used for the treatment of benign stage-2 (active), stage-3 (aggressive) and low-grade malignant stage IA skeletal tumours. ${ }^{27-30}$ It is often advocated to avoid extensive surgical destruction of tissue. ${ }^{26-30}$ Intralesional resection is performed by curettage. Adjuvant treatment is currently given by spraying liquid nitrogen into the bony cavity. This method must be considered marginal by oncologic principles. ${ }^{10}$ The advantage, compared with local resection, is that the supportive function of bone is preserved and reconstructive surgery can be limited. In studies on the extent of the effect of freezing on bone segments in vivo, Gage ${ }^{31}$ found that the temperature gradient was steep and that at approximately $2 \mathrm{~cm}$ from the freezing source no freezing of bone occurred, even after 15 minutes. All the frozen bone was devitalised within one week. Osteogenesis originating from normal bone and periosteum adjacent to the frozen segment, however, was seen within several days. Revitalisation by simultaneous resorption and reossification took several months. ${ }^{31,32}$ The minimum temperature necessary for a cytotoxic effect on invasive cancer cells is believed to be $-50^{\circ} \mathrm{C}$ to $-60^{\circ} \mathrm{C} .^{33}$ Rapid cooling (more than $100^{\circ} \mathrm{C} / \mathrm{min}$ ) and slow thawing $\left(1^{\circ} \mathrm{C}\right.$ to $\left.10^{\circ} \mathrm{C} / \mathrm{min}\right)$ allows the highest cell death rates. ${ }^{32,34}$ The freeze and thaw cycles must be repeated several times because living tissue is able to resist thermal injury and it is technically difficult to achieve optimal conditions for cell death in all areas of the lesions. To compensate, repetition of freeze and thaw cycles is a practical solution and is safe especially at the periphery of the lesion. ${ }^{34-36}$ In the early days of cryotherapy liquid nitrogen was poured directly into a curetted tumour cavity. ${ }^{28}$ We prefer spraying liquid nitrogen, in every direction needed, because it increases the contact area of the coolant with the irregular walls of the cavity, and the freezing process is more easily controlled.

Although the cryotherapeutic technique and its potential benefits have been known for a long time, it is infrequently adopted in orthopaedic practice. This is probably due to the high incidence of complications, especially postoperative fractures and wound infections, that have been reported. $^{26,28}$ Among our patients there was one postoperative fracture due to trauma. There were two deep infections which needed additional surgery. We do not use tourniquets, in order to keep nerves and skin vascularised and thereby protect them from freezing injury. Nerve injuries appear to recover completely. Gas embolism is possible, and there has been one reported mortality. ${ }^{29,37}$ The complication rate becomes less as experience with cryotherapy increases. $^{27}$

We found that cryotherapy as an adjuvant to curettage of aneurysmal bone cysts is associated with a local recurrence rate of $4 \%$. The only recurrence we had was probably due to technique as only one cycle of cryotherapy had been used. Marcove et $\mathrm{al}^{5}$ reported a recurrence rate of $18 \%$ which after additional treatments with the same technique decreased to $4 \%$. Marginal and wide resection of aneurysmal bone cysts lead to comparable local control, but more extensive reconstructive surgery is then needed, with associated morbidity. In general, we recommend the use of cryotherapy as an adjuvant to curettage for the treatment of aneurysmal bone cysts (Fig. 1). The use of a bone graft allowed for consolidation in all cases. In expendable bones (e.g. proximal fibula, ribs) marginal resection appears to be sufficient. ${ }^{2}$ Superselective embolisation with or without irradiation may be considered for aneurysmal bone cysts located in anatomical positions which are very difficult to treat surgically, like vertebral and sacral lesions. ${ }^{2,8,14}$

No benefits in any form have been received or will be received form a commercial party related directly or indirectly to the subject of this article.

\section{REFERENCES}

1. Kransdorf MJ, Sweet DE. Aneurysmal bone cyst: concept, controversy, clinical presentation, and imaging. AJR 1995;164:573-80.

2. Campanacci M, Capanna R, Picci P. Unicameral and aneurysmal bone cysts. Clin Orthop 1986;204:25-36.

3. Clough JR, Price CH. Aneurysmal bone cyst: pathogenesis and long term results of treatment. Clin Orthop 1973;97:52-63.

4. Freiberg AA, Loder RT, Heidelberger KP, Hensinger RN. Aneurysmal bone cysts in young children. J Pediatr Orthop 1994; 14:86-91.

5. Marcove RC, Sheth DS, Takemoto S, Healey JH. The treatment of aneurysmal bone cyst. Clin Orthop 1995;311:157-63.

6. Ruiter DJ, van Rijssel TG, van der Velde EA. Aneurysmal bone cysts: a clinicopathological study of 105 cases. Cancer 1977; 39:2231-9.

7. Cole WG. Treatment of aneurysmal bone cysts in childhood. J Pediatr Orthop 1986;6:326-9.

8. Szendröi M, Cser I, Konya A, Renyi-Vamos A. Aneurysmal bone cyst: a review of 52 primary and 16 secondary cases. Arch Orthop Trauma Surg 1992;111:318-22.

9. Oeseburg HB, Rogge CW, Schraffordt Koops H, Oldhof J. Cryosurgical treatment of aneurysmal bone cysts. J Surg Oncol 1978; 10:9-20. 
10. Enneking WF. A system of staging musculoskeletal neoplasms. Clin Orthop 1986;204:9-24.

11. Koskinen EV, Visuri TI, Holmstrom T, Roukkula MA. Aneurysmal bone cyst: evaluation of resection and of curettage in 20 cases. Clin Orthop 1976;118:136-46.

12. Martinez V, Sissons HA. Aneurysmal bone cyst: a review of 123 cases including primary lesions and those secondary to other bone pathology. Cancer 1988;61:2291-304.

13. Morton KS. Aneurysmal bone cyst: a review of 26 cases. Can J Surg 1986;29:110-5.

14. Nobler MP, Higinbotham NL, Phillips RF. The cure of aneurysmal bone cyst: irradiatio superior to surgery in an analysis of 33 cases. Radiology 1968;90:1185-92.

15. Vergel De Dios AM, Bond JR, Shives TC, McLeod RA, Unni KK. Aneurysmal bone cyst: a clinicopathologic study of 238 cases. Cancer 1992;69:2921-31.

16. Enneking WF. Aneurysmal bone cyst. In: Musculoskeletal tumor surgery. New York: Churchill Livingstone, 1983:1513-29.

17. Biesecker JL, Marcove RC, Huvos AG, Mikè V. Aneurysmal bone cysts: a clinicopathologic study of 66 cases. Cancer 1970;26:615-25.

18. Farsetti P, Tudisco C, Rosa M, Pentimalli G, Ippolito E. Aneurysmal bone cyst: long-term follow-up of 20 cases. Arch Orthop Trauma Surg 1990;109:221-3.

19. Kreicbergs A, Lonnqvist PA, Nilsson B. Curettage of benign lesions of bone: factors related to recurrence. Int Orthop 1985;8:287-94.

20. van Loon CJ, Veth RP, Pruszczynski M, Lemmens JA, van Horn JR. Aneurysmal bone cyst: long-term results and functional evaluation. Acta Orthop Belg 1995;61:199-204.

21. Slowick FA Jr, Campbell CJ, Kettelkamp DB. Aneurysmal bone cyst: an analysis of thirteen cases. J Bone Joint Surg [Am] 1968; 50-A:1142-51.

22. Schiller CH, Ritschl P, Windhager R, Kropej D, Kotz R. The incidence of recurrence in phenol-treated and non-phenol-treated bone cavities following intralesional resection of non-malignant bone tumours. Z Orthop 1989;127:398-401.
23. Capanna R, Sudanese A, Baldini N, Campanacci M. Phenol as an adjuvant in the control of local recurrence of benign neoplasms of bone treated by curettage. Ital J Orthop Traumatol 1985;11:381-8.

24. Rock MG. Treatment of bone cysts and giant cell tumors. Current opinion 1990;1:423-34.

25. Malawer MM, Dunham W. Cryosurgery and acrylic cementation as surgical adjuncts in the treatment of aggressive (benign) bone tumors: analysis of 25 patients below the age of 21. Clin Orthop 1991; 262:42-57.

26. Trent C, Byl FM. Aneurysmal bone cyst of the mandible. Ann Otol Rhinol Laryngol 1993;102:917-24.

27. Marcove RC, Stovell PB, Huvos AG, Bullough PG. The use of cryosurgery in the treatment of low and medium grade chondrosarcoma: a preliminary report. Clin Orthop 1977;122:147-56.

28. Marcove RC, Weis LD, Vaghaiwalla MR, Pearson R, Huvos AG. Cryosurgery in the treatment of giant cell tumors of bone: a report of 52 consecutive cases. Cancer 1978;41:957-69.

29. Marcove RC. A 17-year review of cryosurgery in the treatment of bone tumours.Clin Orthop 1982;163:231-4

30. Jacobs PA, Clemency RE Jr. The closed cryosurgical treatment of giant cell tumor. Clin Orthop 1985;192:149-58.

31. Gage AA. Cryosurgery for cancer. Compr Ther 1984;10:61-9.

32. Kerschbaumer F, Russe W, Weiser G, Bauer R. Cryolesions of bone. Arch Orthop Trauma Surg 1980;96:5-9.

33. Gage AA. What temperature is lethal for cells? J Dermatol Surg Oncol 1979;5:459-60.

34. Neel JB, Ketcham AS, Hammond WG. Requisites for successful cryogenic surgery of cancer. Arch Surg 1971;102:45-8.

35. Gill W, Frazer J, Carter D. Repeated freeze-thaw cycles in cryosurgery. Nature 1968;219:410-3.

36. Gage AA. Experimental cryogenic injury of the palate: observations pertinent to cryosurgical destruction of tumors. Cryobiology 1978; $15: 415-25$.

37. Schreuder HWB, van Beem HB, Veth RP. Venous gas embolism during cryosurgery for bone tumors. J Surg Oncol 1995;60:196-200. 